\title{
Pengaruh Margin Keuntungan dan Inflasi terhadap Pembiayaan pada BRI Syariah Jambi ${ }^{1}$
}

\author{
Nova Erliyana \& Rofiqoh Ferawati \\ Pascasarjana UIN Sulthan Thaha Saifuddin Jambi \\ E-mail: erliyananova@gmail.com
}

\begin{abstract}
This study aims to determine the effect of the level of inflation and profit margins on the financing of BRI Syariah Bank Jambi. Data sources in the form of the 2014-2018 BRI Syariah Bank Annual Report, especially in Profit Margin and Financing pages and also from Bank Indonesia Publications on inflation rate. The approach in this research is quantitative with descriptive statistical techniques. The regression test used is multiple regression test with $t$ test, $F$ test and determination coefficient test $R 2$. The statistical tool uses the Eviews program version 6. The results showed that the effect of inflation (X1) on $Y$ was a significance value less than $0.05(0.0000<0.05)$. then the obtained t table with $d f=48$ is equal to 1,677. then obtained tcount (-) 6.312717> $t$ table (1.677) so that $\mathrm{HO}$ is rejected and $\mathrm{Ha}$ is accepted. Therefor inflation has a significant effect on financing disbursed by PT.BRI Syariah in Jambi. While the Profit Margin (X2) obtained by $t$ count of 1.885936, then the obtained $t$ table with $d f=48$ is 1.677. then obtained tcount (1.885936)> t table (1.677) so that HO is rejected and Ha is accepted. The profit margin has a significant effect on the financing distributed to BRI Syariah Jambi. A constant value of 16,083,290 states that if the independent variable is considered constant, the average disbursed financing is $16.08 \%$. every one percent increase in inflation, the channeled financing will decrease by 0.422788 or $42.78 \%$. Every one percent increase in the profit margin, the financing channeled will increase by $2.14 \%$.
\end{abstract}

Keywords: Inflation, profit margin, financing, BRIS

Abstrak: Penelitian ini bertujuan untuk mengetahui pengaruh margin keuntungan
dan inflasi terhadap pembiayaan Bank BRI Syariah Jambi. Sumber data berasal dari
Laporan Tahunan Bank BRI Syariah khususnya terkait margin keuntungan dan
pembiayaan serta publikasi Bank Indonesia untuk melihat tingkat inflasi.
Pendekatan penelitian adalah kuantitatif dengan teknik statistik deskriptif. Uji
regresi yang digunakan adalah uji regresi berganda dengan Uji $t$, Uji $\mathrm{F}$ dan Uji
Koefisien Determinasi $\mathrm{R}^{2}$. Alat bantu statistik menggunakan program Eviews versi 6 .
Hasil penelitian menunjukkan bahwa pengaruh Inflasi $\left(\mathrm{X}_{1}\right)$ terhadap $\mathrm{Y}$ adalah nilai
signifikansi lebih kecil dari $0.05(0.0000<0.05)$. maka diperoleh $\mathrm{t}_{\text {tabel }}$ dengan df $=48$
adalah sebesar 1.677 . maka diperoleh $\mathrm{t}_{\text {hitung }}(-) 6.312717>\mathrm{t}_{\text {tabel }}(1.677)$ sehingga $\mathrm{H}_{0}$
ditolak dan $\mathrm{H}_{\mathrm{a}}$ diterima. Maka Inflasi berpengaruh signifikan terhadap pembiayaan
yang disalurkan oleh PT.BRI Syariah di Jambi. Sedangkan Margin Keuntungan $\left(\mathrm{X}_{2}\right)$
diperoleh $\mathrm{t}_{\text {hitung }}$ sebesar 1.885936 maka diperoleh $\mathrm{t}_{\text {tabel }}$ dengan $\mathrm{df}=48$ adalah sebesar
1.677. maka diperoleh $\mathrm{t}_{\text {hitung }}(1.885936)>\mathrm{t}_{\text {tabel }}(1.677)$ sehingga $\mathrm{H}_{0}$ ditolak dan $\mathrm{H}_{\mathrm{a}}$

1 Tulisan ini adalah bagian dari tesis penulis dari judul yang sama yang dibimbing oleh Prof. Dr. Mukhtar, M.Pd dan Dr. Rofiqoh Ferawati, M.EI, dan telah diujikan pada November 2019. 
diterima. Margin keuntungan berpengaruh signifikan terhadap pembiayaan yang disalurkan BRI Syariah Jambi. nilai konstanta sebesar 16.083.290 menyatakan bahwa jika variabel independen dianggap konstan, maka rata-rata pembiayaan yang disalurkan $16,08 \%$. setiap ada peningkatan satu persen Inflasi maka pembiayaan yang disalurkan akan turun sebesar 0.422788 atau $42,78 \%$. Setiap ada peningkatan satu persen margin keuntungan maka pembiayaan yang disalurkan akan meningkat sebesar 2,14\%.

Kata-kata kunci: Inflasi, margin keuntungan, pembiayaan, BRIS.

\section{Pendahuluan}

Perbankan syariah moderen telah dirasakan manfaatnya dalam kehidupan sehari-hari. Pengetahuan tentang perbankan syariah penting untuk diketahui, baik oleh konsumen perbankan syariah maupun oleh masyarakat umum. Tulisan ini merupakan bagian dari karya ilmiah tesis penulis dengan bimbingan penulis kedua, yang akan mengurai apa yang dimaksud margin, bagaimana dengan penetapan bunga dan mengapa inflasi bisa mempengaruhi pembiayaan pada bank yang menjadi fokus kajian, yaitu Bank Rakyat Indonesia Syariah (BRIS) Jambi.

Inflasi nol persen dalam ekonomi tidak mungkin terwujud secara berkesinambungan dan lama. Oleh sebab itu dalam perekonomian yang sangat stabil sekalipun, inflasi merayap akan selalu berlaku. Inflasi menimbulkan beberapa efek buruk terhadap perekonomian, yaitu dapat memperburuk prospek pertumbuhan jangka panjang, mengurangi pendapatan riil, mengurangi nilai kekayaan berbentuk uang dan memperburuk distribusi pendapatan. ${ }^{2}$ Di Indonesia industry perbankan syariah sangat prosfektif ditunjukkan oleh kinerjanya yang kuat dalam dua dekade terakhir. target 5\% pertama kali diumumkan oleh Indonesia di bawah program yang disebut program akselerasi 2007-2008 dan direncanakan akan direalisasikan pada akhir 2008.

Peran bank sangat besar dalam mendorong pertumbuhan ekonomi suatu negara. Semua sektor usaha baik sektor industri, perdagangan, pertanian, perkebunan, jasa, perumahan, dan lainnya sangat membutuhkan bank sebagai mitra dalam mengembangkan usahanya. Pemerintah dalam suatu negara terus menerus melakukan upaya peningkatan pertumbuhan ekonomi melalui perbaikan dan peningkatan kinerja bank sebagai lembaga keuangan dan lokomotif pembangunan ekonomi. Lembaga keuangan bank yang mempunyai peranan yang strategis dalam membangun suatu perekonomian negara.

Di antaranya yang dilakukan Lembaga Keuangan Syariah (LKS) berbasis Hukum Syariah yang difatwakan Dewan Syariah Nasional Majelis Ulama Indonesia (DSN MUI) adalah Pembiayaan Mudharabah (Qiradh), Pembiayaan Musyarakah, Pembiayaan Ijarah, Wakalah, Akad Mudharabah Musyarakah,

2 Boediono, Pengantar Ilmu Ekonomi Makro, Yogyakarta: BPFE,2016, hlm. 158. 
dan Akad Kafalah. ${ }^{3}$ Ahli moneter atau monetaris berpendapat bahwa inflasi merupakan fenomena moneter yang timbul sebagai akibat bertambahnya jumlah uang. Dengan demikian ahli moneter menyalahkan bank sentral sebagai biang keladi terjadinya inflasi. Sebaliknya Keynesian berpendapat bahwa kenaikan agregate tidak saja berasal dari bank sentral, tetapi juga dari kenaikan pengeluaran investasi oleh pengusaha dan pemerintah maupun pengeluaran konsumsi.

Sistem perbankan syariah yang ingin diwujudkan oleh Bank Indonesia adalah perbankan syariah yang modern, yang bersifat universal, terbuka bagi seluruh masyarakat Indonesia tanpa terkecuali. Sebuah sistem perbankan yang menghadirkan bentuk-bentuk aplikatif dari konsep ekonomi syariah yang dirumuskan secara bijaksana, konteks kekinian yang menjawab permasalahan yang sedang dihadapi oleh bangsa Indonesia, dan dengan tetap memperhatikan kondisi sosio-kultural di mana bangsa ini menuliskan perjalanan sejarahnya. Hanya dengan cara demikian, maka upaya pengembangan sistem perbankan syariah akan senantiasa dilihat dan diterima oleh segenap masyarakat Indonesia sebagai bagian dari solusi atas berbagai permasalahan negeri.

Menurut teori ini, inflasi terjadi karena suatu masyarakat ingin hidup diluar batas kemampuan ekonominya. Dalam hal terjadinya inflasi keynesian lebih menyalahkan pemerintah karena pengeluaran melebihi pendapatan (defisit anggaran belanja). ${ }^{4}$ Hubungan laju inflasi dengan tingkat suku bunga digambarkan melalui teori Fisher Effect. Saekhu mengutip Fisher, bahwa kenaikan 1 persen tingkat inflasi menyebabkan kenaikan 1 persen dalam tingkat suku bunga nominal. ${ }^{5}$ Inflasi akan berpengaruh terhadap kinerja lembaga keuangan syariah. Sebagaimana yang diungkapkan menurut Teori Bejana Berhubungan kebijakan moneter konvensional akan mempunyai pengaruh terhadap perbankan syariah. ${ }^{6}$ Adapun margin keuntungan dan pembiayaan merupakan bagian dari perbankan syariah. Tulisan ini dilatari oleh penelitian untuk mengetahui bagaimana pengaruh inflasi terhadap pembiayaan pada BRI Syariah Jambi, dan bagaimana pengaruh margin keuntungan terhadap pembiayaan pada BRI Syariah Jambi serta untuk mengetahui bagaimana pengaruh inflasi dan margin keuntungan terhadap pembiayaan pada BRI Syariah Jambi.

\section{Bank Konvensional dan Bank Syariah}

${ }^{3}$ Boediono, Pengantar Ilmu Ekonomi Makro, Yogyakarta: BPFE,2016, hlm. 158.

${ }^{4}$ Nopirin, Ekonomi Moneter, Yogyakarta: BPFE,2013, hlm. 90 - 91.

${ }^{5}$ Riza Waljianah dan Farah Wulandari, "Determinasi Tingkat Suku Bunga Pinjaman Perbankan di Indonesia (Periode Juli 2005 - Desember 2011), Jurnal Ilmiah, Universitas Brawijaya, Malang, 2013, hlm. 2.

6 Saekhu, "Pengaruh Inflasi Terhadap Kinerja Pembiayaan Bank Syariah, Volume Pasar, Uang Antar Bank Syariah dan Posisi Outstanding Sertifikat Wadiah Bank Indonesia”, Jurnal ECONOMICA Pemikiran dan Penelitian Ekonomi Islam, Vol. VI, 2015, hlm. 109. 
Salah satu bank yang menjalankan kegiatan usahanya secara konvensional adalah Bank Konvensional dan berdasarkan jenisnya terdiri atas Bank Umum Konvensional dan Bank Perkreditan Rakyat. Sedangkan Bank Syariah adalah Bank yang menjalankan kegiatan usahanya berdasarkan Prinsip Syariah dan menurut jenisnya terdiri atas Bank Umum Syariah dan Bank Pembiayaan Rakyat Syariah. Prinsip Syariah adalah prinsip hukum Islam dalam kegiatan perbankan berdasarkan fatwa yang dikeluar-kan oleh lembaga yang memiliki kewenangan dalam penetapan fatwa di bidang syariah. ${ }^{7}$

Berbagai jenis akad yang diterapkan oleh bank syariah dapat dibagi kedalam enam kelompok pola yaitu: a. Pola titipan, seperti wadi'ah yad amanah dan wadi'ah yad dhamanah. b. Pola pinjaman, seperti qardh dan qardhul hasan. c. Pola bagi hasil, seperti mudharabah dan musharakah. d. Pola jual beli, seperti murabahah, salam dan istishna. e. Pola sewa, seperti ijarah dan ijarah wa iqtina, dan f. Pola lainnya, seperti wakalah, kafalah, hiwalah, ujr, sharf dan rahn. ${ }^{8}$ Perbedaan pokok antara sistem bank Konvensional dengan sistem bank syariah pada hukum yang mendasarinya juga meilikiperbedaan pada setiapsistem yang digunakan misalnya dala hal investasi. Pada bank syariah, seorang akan diperkenankan meminjam dana apabila jenis usaha yang diajukannnya adalah usaha yang halal dan baik, seperti pertanian, peternakan, dagang, dan lain sebagainya. Sementara itu, pada bank konvensional, seseorang boleh mengajukan pinjaman terhadap usaha-usaha yang diizinkan atas hukum positi.

Sistem pembagian keuntungan antara bank konvensional dan bank syariah juga berbeda. Bank konvensional menerapkan sistem bunga tetap atau bunga mengambang pada setiap pinjaman yang diberikan pada nasabah. Oleh karena itu, bank konvensional menganggap bahwa usaha yang dijalankan oleh nasabah akan selalu untung. Hal ini berbeda dengan sistem pembagian keuntungan yang diterapkan bank syariah. Pada bank syariah, keuntungan dari penggunaan modal dibagi sesuai dengan akad yang disepakati di awal. Bank syariah akan tetap memperhatikan kemungkinan untung atau rugi usaha yang dibiayainya tersebut. Jika dirasa tidak menguntungkan, bank syariah akan menolak pengajuan pinjaman yang nasabahnya.

Bank Syariah sebagaimana bank Konvensional memiliki fungsi sebagai perantara jasa keuangan (financial intermediary), memiliki tugas pokok yaitu: menghimpun dana dari masyarakat dan menyalurkanya kembali kepada masyarakat dalam bentuk fasilitas pembiayaan. Istilah lain Bank Syariah adalah Bank Islam. Secara akademik, istilah Islam dan Syariah memang mempunyai pengertian yang berbeda. Namun secara teknis untuk penyebutan Bank Islam dan Bank Syariah mempunyai pengertian yang sama. Bank Islam berarti bank yang tata cara beroperasinya didasarkan pada tata

${ }^{7}$ Muhammad, Manajemen Dana Bank Syariah, Jakarta: Raja Grafindo Persada, 2014, hlm.17

${ }^{8}$ Ascarya, Op. Cit, hlm. 41 
cara bermuamalat secara Islam, yakni mengacu kepada ketentuan- ketentuan Al-Qur'an dan Al-Hadis. ${ }^{9}$

Perbedaan Sistem Bank Konvensional dan Bank Syariah

\begin{tabular}{|c|c|c|}
\hline Perbedaan Aspek & Bank Islam Konvensional & Bank Syariah \\
\hline $\begin{array}{c}\text { Fungsi dan Kegiatan } \\
\text { Bank }\end{array}$ & Intermediasi, Jasa Keuangan & $\begin{array}{l}\text { Intermediasi, Jasa } \\
\text { Keuangan, Manager } \\
\text { Investasi, Investor }\end{array}$ \\
\hline $\begin{array}{l}\text { Mekanisme dan } \\
\text { Objek Usaha }\end{array}$ & Tidak antiriba dan antimaysir & $\begin{array}{l}\text { Antiriba dan } \\
\text { antimaysir }\end{array}$ \\
\hline $\begin{array}{l}\text { Prinsip Dasar } \\
\text { Operasi }\end{array}$ & $\begin{array}{l}\text { 1. Bebas Nilai (prinsip } \\
\text { materialis) } \\
\text { 2. Uang sebagai komoditi } \\
\text { 3. Bunga }\end{array}$ & $\begin{array}{c}\text { 1. Tidak bebas nilai } \\
\text { (prinsip syariah } \\
\text { Islam) }\end{array}$ \\
\hline Prioritas Pelayanan & Kepentingan Pribadi & Kepentingan Publik \\
\hline Orientasi & Keuntungan & $\begin{array}{l}\text { Tujuan sosial- } \\
\text { ekonomi Islam, } \\
\text { keuntungan }\end{array}$ \\
\hline Bentuk & Bank komersial & $\begin{array}{c}\text { Bank komersial, bank } \\
\text { pembangunan, bank } \\
\text { universal atau multi- } \\
\text { porpose }\end{array}$ \\
\hline Evaluasi Nasabah & $\begin{array}{l}\text { Kepastian pengembalian pokok } \\
\text { dan bunga }\end{array}$ & $\begin{array}{l}\text { Lebih hati-hati karena } \\
\text { partisipasi dalam } \\
\text { risiko }\end{array}$ \\
\hline Hubungan Nasabah & Terbatas debitor-kreditor & $\begin{array}{c}\text { Erat sebagai mitra } \\
\text { usaha }\end{array}$ \\
\hline $\begin{array}{l}\text { Sumber Likuiditas } \\
\text { Jangka Pendek }\end{array}$ & Pasar Uang, Bank Sentral & $\begin{array}{c}\text { Pasar Uang Syariah, } \\
\text { Bank Sentral }\end{array}$ \\
\hline $\begin{array}{l}\text { Pinjaman yang } \\
\text { diberikan }\end{array}$ & $\begin{array}{c}\text { Komersial dan nonkomersial } \\
\text { berorientasi laba }\end{array}$ & $\begin{array}{c}\text { Komersial dan } \\
\text { nonkomersial } \\
\text { berorientasi nirlaba } \\
\end{array}$ \\
\hline $\begin{array}{l}\text { Lembaga Penyelesai } \\
\text { Sengketa }\end{array}$ & Pengadilan, Arbitrase & $\begin{array}{c}\text { Pengadilan, Badan } \\
\text { Arbitrase Syariah } \\
\text { Nasional } \\
\end{array}$ \\
\hline $\begin{array}{l}\text { Struktur Organisasi } \\
\text { Pengawas }\end{array}$ & $\begin{array}{c}\text { Dewan pengawas terdiri dari BI, } \\
\text { Bapepam, Komisaris dan adanya } \\
\text { Dewan Pengawas Syariah }\end{array}$ & $\begin{array}{c}\text { Dewan pengawas } \\
\text { terdiri dari BI, } \\
\text { Bapepam, Komisaris }\end{array}$ \\
\hline Investasi & Halal atau haram & Halal \\
\hline
\end{tabular}

Berdasarkan tabel diatas dapat dijelaskan bahwa bank syariah dan bank konvensional pada hukum yang mendasarinya juga terdapat perbedaan pada setiap sistem yang digunakan, misalnya dalam hal investasi. Pada bank

9 Warkum Soemitro, Asas perbankan Islam \& Lembaga-lembaga terkait amui, Takaful, dan pasar modal di Indonesia, Jakarta: Raja Grafindo Persada, 2004, hlm. 5. 
syariah, seorang akan diperkenankan meminjam dana apabila jenis usaha yang diajukannnya adalah usaha yang halal dan baik, seperti pertanian, peternakan, dagang, dan lain sebagainya. Sementara itu, pada bank konvensional, seseorang boleh mengajukan pinjaman terhadap usaha-usaha yang diizinkan atas hukum positif. Usaha yang tidak halal (riba) tapi diakui hukum positif di Indonesia akan tetap diterima dalam pengajuan pinjaman. Sebagaimana dijelaskan dalam surah Az-Zumar ayat 39 yang artinya "Katakanlah (Muhammad), "Wahai kaumku! Berbuatlah menurut kedudukanmu, aku pun berbuat pula. Kelak kamu akan mengetahui".

Maksud dari ayat tersebut adalah Islam melarang setiap pembayaran bunga (riba) atas berbagai bentuk pinjaman, apakah pinjaman itu berasal dari teman, perusahaan perorangan, pemerintah ataupun institusi lainnya.

\section{Inflasi dalam Ekonomi Konvensional}

Salah satu yang dianggap sebagai fenomena moneter yaitu inflasi hal tersebut karena terjadinya penurunan nilai unit penghitungan moneter terhadap suatu komoditas. Inflasi adalah gejala yang menunjukkan kenaikan tingkat harga umum yang berlangsung terus-menerus. Kenaikan harga tersebut dimaksudkan bukan terjadi sesaat. ${ }^{10}$ Inflasi adalah suatu kondisi atau keadaan terjadinya kenaikan harga untuk semua barang secara terusmenerus yang berlaku pada suatu perekonomian tertentu. Inflasi yang tinggi mengancam perekonomian. ${ }^{11}$

Inflasi biasanya menunjukkan pada harga-harga konsumen, tetapi bisa juga menggunakan harga-harga lain (harga perdagangan besar, upah, harga, asset dan sebagainya). Biasanya diekspresikan sebagai persentase perubahan angka indeks. Tingkat harga yang melambung sampai $100 \%$ atau lebih dalam setahun (hiperinflasi), menyebabkan hilangnya kepercayaan masyarakat terhadap uang, sehingga masyarakat cenderung menyimpan aktiva mereka dalam bentuk lain, seperti real estate atau emas yang biasanya bertahan nilainya di masa-masa Inflasi. ${ }^{12}$ Menurut ilmu ekonomi modern, terdapat dua jenis inflasi yang berbeda satu sama lain, yaitu inflasi karena dorongan biaya (cost-push inflation) dan inflasi karena meningkatnya permintaan (demand-pull inflation). ${ }^{13}$

Berdasarkan pengertian diatas dapat dipahami bahwa inflasi merupakan situasi ekonomi yang terjadi dengan kondisi adanya kelebihan jumlah mata uang beredar dibandingkan nilai barang dan jasa yang ada secara riil. Sehingga oleh karena permintaan barang dan jasa tinggi sementara penawaran terbatas, maka nilai mata uang mengalami penurunan

\footnotetext{
${ }^{10}$ Rozalinda, Ekonomi Islam: Teori dan Aplikasinya pada Aktivitas Ekonomi, Jakarta: Rajawali Pers, 2014, hlm. 298.

11 Detri Karya, Makroekonomi: Pengantar untuk Manajemen, Jakarta: Rajawali Pers, 2016, hlm. 89.

12 Nurul Huda, dkk, Ekonomi Islam: Pendekatan Teoritis, Jakarta: Kencana, 2008, hlm. 175 - 176.

${ }^{13}$ Nurul Huda, dkk, hlm.177.
} 
dibandingkan harga barang atau jasa yang melambung tinggi. Untuk mengatasi persoalan inflasi, ekonomi kovensional memiliki berbagai kebijakan. Di antaranya adalah kebijakan moneter oleh Bank Sentral yang disebut dengan diskonto rate, sangat berkaitan dengan bunga. Tingkat inflasi adalah faktor penting yang dapat digunakan untuk menganalisa pergerakan tingkat suku bunga. Hubungan laju inflasi dengan tingkat suku bunga digambarkan melalui teori Fisher Effect. Menurut Fisher, kenaikan 1 persen dalam tingkat inflasi menyebabkan kenaikan 1 persen dalam tingkat suku bunga nominal. ${ }^{14}$

\section{Pandangan Islam tentang Inflasi}

Ekonomi Islam merupakan ikhtiar pencarian sistem ekonomi yang lebih baik setelah ekonomi kapitalis gagal total. Dalam Islam tidak dikenal dengan inflasi, karena mata uang yang dipakai adalah dinar dan dirham, yang mana mempunyai nilai yang stabil dan dibenarkan oleh Islam. ${ }^{15}$ Sebagaimana dikemukakan di atas, inflasi secara substansi bukanlah ditentukan oleh jenis mata uang yang digunakan. Meskipun uang yang digunakan adalah uang yang bernilai instrinsik dan ekstrinsik, jika kebijakan moneter yang digunakan adalah kebijakan moneter yang kontra produktif dengan keinginan untuk menghilangkan inflasi, maka inflasi tetap akan terjadi.

Bank Islam atau di Indonesia disebut bank syariah merupakan lembaga keuangan yang berfungsi memperlancar mekanisme ekonomi di sektor riil melalui aktivitas kegiatan usaha (investasi, jual beli atau lainnya) berdasarkan prinsip Syariah, yaitu aturan perjanjian berdasarkan hukum Islam antara bank dan pihak lain untuk penyimpanan dana dan atau pembiayaan kegiatan usaha, atau kegiatan lainnya yang dinyatakan sesuai dengan nilai-nilai Syariah yang bersifat makro maupun ekonomi.

Krisis ekonomi di kawasan Asia Tenggara berawal dari devaluasi Baht (mata uang Thailand) pada bulan Juli 1997. Pada dasarnya adalah akibat buruknya kualitas lembaga-lembaga keuangan yang menerapkan suku bunga sebagai sistem ribawi yang ternyata gagal berfungsi sebagai alat indirect screening mechanism. Bahkan ia sendiri berpotensi menjadi trouble maker yang melahirkan tiga macam krisis, krisis keuangan dan moneter, krisis pasar saham, dan krisis perbankan. ${ }^{16}$

\footnotetext{
${ }^{14}$ Riza Waljianah dan Farah Wulandari, “Determinasi Tingkat Suku Bunga Pinjaman Perbankan di Indonesia Periode Juli 2005 - Desember 2011, Jurnal Ilmiah, Universitas Brawijaya Malang, 2013, hlm. 2.

${ }^{15}$ Nurul Huda, dkk, Ekonomi Makro Islam Pendekatan Teoritis, Jakarta: Kencana Prenada Media Group, 2009, hlm. 189.

16 Nurul Huda, dkk, Ekonomi Makro Islam Pendekatan Teoritis, Jakarta: Kencana Prenada Media Group, 2009, hlm. 233.
} 
Beberapa mazhab ekonomi islam berpendapat dan menjelaskan tentang kebijakan ekonomi yang dapat dijadikan sebagai instrumen moneter untuk mengatasi persoalan inflasi, yakni sebagai berikut: ${ }^{17}$

a. Mazhab pertama (Iqtisaduna)

Menurut padangan mazhab ini, di antaranya Muhammad Baqr as-Sadr, ekonomi Islam akan lahir secara nyata dalam kehidupan masyarakat yang secara total (kaffah) menjalankan syariat Islam. Persoalan ekonomi selama ini terjadi oleh karena penyimpangan yang dilakukan oleh manusia, seperti pendistribusian kekayaan secara tidak seimbang serta ketidakbersyukuran manusia terhadap nikmat Allah Swt.

b. Mazhab kedua (Mainstream)

Menurut pandangan mazhab ini, di antaranya Chapra, ajaran Islam yang mengajarkan bahwa harga ditentukan oleh mekanisme pasar, merupakan suatu peluang untuk mewujudkan harga yang sesuai dengan maqa<sidnya. Permintaan uang dalam Islam mesti diarahkan terhadap sektor investasi yang bersifat riil. Menurut mazhab ini menekan laju peredaran uang melebihi jumlah barang adalah dengan zakat. Karena zakat membatasi seseorang untuk melakukan permintaan uang untuk kepentingan yang tidak produktif serta spekulatif. Menurut mazhab kedua, permintaan uang dapat direpresentasikan dengan menggunakan persamaan berikut ini:

Penjelasan:

$$
\mathrm{Md}=\mathrm{f}(\mathrm{Ys}, \mathrm{S}, \pi)
$$

$\mathrm{Md}=$ Permintaan uang

Ys = Barang dan jasa

$\mathrm{S}=$ Nilai-nilai dan institusi sosial, termasuk zakat

$\Pi=$ Tingkat bagi hasil dan resiko

c. Mazhab ketiga (Alternatif)

Menurut mazhab yang ketiga, untuk mewujudkan stabilitas nilai mata uang adalah mewujudkan sistem yang terintegrasi antara moneter dengan sektor riil. Konsekuensi positif mengatur jumlah peredaran uang sesuai dengan kondisi ekonomi riil adalah mengantisipasi terjadinya inflasi. Selain itu juga dapat menjaga kestabilan nilai tukar mata uang. Permintaan dan penawaran uang didasarkan atas perhitungan rasio pencadangan uang antara Bank Sentral dengan Bank Umum (komersial).

Untuk membangun kedaulatan ekonomi dan tata kelola perekonomian yang baik, merupakan prasyarat utama bagi tercapainya kondisi kesejahteraan masyarakat dan bangsa. Penegakan kedaulatan ekonomi merupakan sebuah keniscayaan. Kedaulatan ekonomi ini adalah hal yang sangat esensial dan fundamental bagi setiap bangsa. Jalan untuk menegakkan kedaulatan ekonomi ini, tidak lain adalah melalui kebijakan ekonomi yang berbasis pada konsep maslahah. Maslahah adalah suatu konsep yang

17 Muhammad Umer Chapra, Monetary Management in An Islamic Economy, Islamic Economic Studies, Vol. 4, No. 1, Desember 1996, hlm. 14 - 15. 
mendasarkan dua aspek utama, yaitu manfaat dan berkah. Agar kebijakan yang dihasilkan dapat membawa manfaat dan keberkahan, maka ada dua syarat yang harus dipenuhi, yaitu: a. Kebijakan tersebut harus sesuai dengan maqashid syariah atau tujuan syariat Islam, yaitu melindungi agama, jiwa, harta, keturunan dan akal. b. Dasar orientasi kebijakan tersebut adalah pada perlindungan kepentingan kaum dhuafa. ${ }^{18}$

\section{Margin Keuntungan}

Ada beberapa pendapat ahli tentang profit margin atau margin keuntungan yang diperoleh badan usaha dalam menjalankan usahanya. Net profit margin adalah ukuran keuntungan yang membandingkan antara laba sesudah bunga dan pajak dibandingkan dengan penjualan. Rasio ini juga dibandingkan dengan rata-rata industri. Rasio ini menunjukkan bahwa pendapatan bersih perusahaan atas penjualan. ${ }^{19}$

Menurut Sutrisno (2009) margin keuntungan yaitu kemampuan perusahaan untuk dapat menghasilkan keuntungan dibandingkan dengan penjualan yang capai. ${ }^{20}$ Werner R. Murhadi (2013) menyebutkan margin keuntungan yaitu mencerminkan kemampuan suatu perusahaan dalam memperoleh laba neto dari setiap penjualannya. Jika semakin tinggi nilai net profit margin, maka itu menunjukkan semakin baik. ${ }^{21}$ Profit margin yaitu perbandingan antara net operating income dengan net sales, perbandingan dimana dinyatakan dalam persentase. ${ }^{22}$ Selisih dari modal dan penjualan merupakan keuntungan atau margin keuntungan yang didapat. Profit margin dapat dikatakan merupakan kemampuan perusahaan untuk menghasilkan keuntungan dibandingkan dengan penjualan yang dicapai. Sebuah rasio yang mengukur seberapa banyak keuntungan operasional bisa diperoleh dari setiap penjualan. ${ }^{23}$

Profit margin yaitu besarnya keuntungan operasi yang dinyatakan dalam prosentase dan jumlah penjualan bersih. Profit Margin ini mengukur tingkat keuntungan yang dapat dicapai oleh perusahaan dihubungkan dengan penjualannya. ${ }^{24}$ Angka ini menunjukkan berapa besar persentase pendapatan bersih yang diperoleh dari setiap penjualan. Semakin besar rasio ini semakin baik karena dianggap kemampuan perusahaan dalam

18 Irfan Syauqi Beik, dkk, Ekonomi Pembangunan Syariah, Jakarta : Rajawali Pers, 2016, hlml. 30 - 31.

${ }^{19}$ Kasmir, Bank dan Lembaga Keuangan Lainnya, Jakarta: PT. Raja Grafindo Persada, 2014, hlm. 56.

20 Umer Chapra dan Habib Ahmed, Corporate Governance Lembaga Keuangan Syariah, Jakarta: Bumi Aksara, 2008, hlm. 98.

21 Thamrin Abdullah dan Francis Tantri, Bank dan Lembaga Keuangan, Jakarta: PT. Raja Grafindo Persada, 2013, hlm. 165.

22 Bambang Riyanto, Dasar-dasar pembelanjaan perusahaan, Yogyakarta: Gajah Mada, 2001, hlm. 37.

${ }^{23}$ Suad Husnan dan Enny Pudjiastuti, Manajemen Keuangan, Yogyakarta: BFEE, 2004, hlm. 74 .

${ }^{24}$ S. Munawir, Analisis laporan Keuangan, Yogyakarta: Liberty, 2007, hlm. 89. 
mendapatkan laba cukup tinggi. ${ }^{25}$ Untuk perhitungan teorinya sebagai berikut: "Rasio laba usaha dengan penjualan neto (profit margin) dihitung dengan membagi laba usaha dengan penjualan neto.

\section{Pembiayaan}

Penyaluran dana pada Bank Syariah disebut dengan pembiayaan. Pembiayaan berdasarkan prinsip syariah terbagi menjadi beberapa prinsip yaitu: berdasarkan prinsip jual beli, bagi hasil dan sewa. ${ }^{26}$ Pembiayaan pada bank syariah sangat penting karena kegiatan pembiayaan ini merupakan salah satu sarana untuk memperoleh kenungan juga untuk menjaga keamanan dana nasabah.

Penyaluran dana dalam bank konvensional, kita kenali dengan istilah kredit atau pinjaman. Sedangkan dalam bank syariah untuk penyaluran dananya kita kenal dengan istilah pembiayaan. Penyaluran dana tersebut harus digunakan dengan benar, adil dan disertai dengan ikatan dan syaratsyarat yang jelas serta saling menguntungkan bagi kedua belah pihak sebagaimana firman Allah dalam Surat An-Nisa ayat 29 yang artinya "Hai orang-orang yang beriman, janganlah kamu saling memakan harta sesamamu dengan jalan yang batil, kecuali dengan jalan perniagaan yang berlaku dengan suka sama suka diantara kamu. Dan janganlah kamu membunuh dirimu; Sesungguhnya Allah adalah Maha Penyayang kepadamu".

Menurut Undang-undang Republik Indonesia nomor 21 tahun 2008 tentang perbankan syariah pembiayaan adalah penyediaan dana atau tagihan yang dipersamakan dengan itu berupa:

a. transaksi bagi hasil dalam bentuk mudharabah dan musyarakah

b. transaksi sewa-menyewa dalam bentuk ijarah atau sewa beli dalam bentuk ijarah muntahiya bittamlik

c. transaksi jual beli dalam bentuk piutang murabahah, salam , dan istishna'

d. transaksi pinjam meminjam dalam bentuk piutang qardh

e. transaksi sewa-menyewa jasa dalam bentuk ijarah untuk transaksi multijasa

berdasarkan persetujuan atau kesepakatan antara Bank Syariah dan/atau UUS dan pihak lain yang mewajibkan pihak yang dibiayai dan/atau diberi fasilitas dana untuk mengembalikan dana tersebut setelah jangka waktu tertentu dengan imbalan ujrah, tanpa imbalan, atau bagi hasil.

Pembiayaan atau financing, yaitu pendanaan yang diberikan oleh suatu pihak kepada pihak lain untuk mendukung investasi yang telah direncanakan, baik dilakukan sendiri atau lembaga. Dengan kata lain pembiayaan adalah pendanaan yang dikeluarkan untuk mendukung investasi yang telah direncanakan. ${ }^{27}$ Didalam bank konvensional keuntungan bank 241.

25 Sofyan Syafri Harahap, Teori Akuntansi, Jakarta: Raja Grafindo Persada, 2011, hlm.

${ }^{26}$ Ascarya, hlm. 32.

27 Veithzal Rivai dan Arviyan Arifin, hlm. 681. 
diperoleh dengan bunga yang dibebankan nasabah, sedangkan didalam bank syariah tidak ada istilah bunga melainkan bank syariah menerapkan sistem bagi hasil. Pembiayaan dengan prinsip bagi hasil dalam bank syariah dibedakan menjadi dua yaitu pembiayaan mudharabah dan pembiayaan musyarakah.

Sesuai dengan akad pengembangan produk, maka bank Islam memiliki banyak jenis pembiayaan. Pembiyaan menurut tujuannya dibedakan menjadi pembiayaan modal kerja dan pembiayaan investasi. Sedangkan jenis pembiayaan dalam bank Islam akan diwujudkan dalam bentuk aktiva produktif dan aktiva tidak produktif. Jenis aktiva produktif pada bank Islam dialokasikan dalam bentuk pembiayaan sebagai berikut:

1. Pembiayaan dengan prinsip bagi hasil meliputi pembiayaan mudharabah dan musyarakah. Mudharabah merupakan penanaman dana dari pemilik dana (shahibul maal) kepada pengelola dana/modal (mudharib) untuk melakukan kegiatan usaha tertentu dengan pembagian menggunakan metode bagi untung rugi (profit and loss sharing) atau metode bagi pendapatan (revenue sharing) antara kedua belah pihak berdasarkan nisbah (bagian keuntungan usaha bagi masing-masing pihak yang besarnya ditetapkan berdasarkan kesepakatan) yang telah disepakati, sedangkan kerugian ditanggung pemilik dana. ${ }^{28}$ Musyarakah adalah perjanjian diantara pemilik dana/modal untuk mencampurkan dana/ modal mereka pada suatu usaha tertentu dengan pembagian keuntungan diantara pemilik dana/modal berdasarkan nisbah yang telah disepakati sebelumnya. ${ }^{29}$

2. Pembiayaan dengan prinsip bagi hasil (piutang) meliputi pembiayaan Murabahah dan Salam. Murabahah Merupakan akad jual beli yang disepakati antara Bank syariah dengan nasabah, dimana bank menyediakan pembiayaan untuk pembelian bahan baku atau modal kerja lainnya yang dibutuhkan nasabah, yang akan dibayar kembali oleh nasabah sebesar harga jual bank (harga beli bank dari pemasok ditambah margin / keuntungan) yang disepakati antara bank Islam dan nasabah. Salam merupakan perjanjian jual beli barang dengan cara pemesanan dengan syarat-syarat tertentu dan pembayaran harga terlebih dulu. ${ }^{30}$

3. Pembiayaan dengan prinsip sewa meliputi pembiayaan Ijarah dan pembiayaan Ijarah Muntahiya Biltamlik/Wa Iqtina. Ijarah merupakan transaksi sewa menyewa atas suatu barang dan atau upah mengupah atas suatu jasa dalam waktu tertentu melalui pembayaran sewa. Ijarah Muntahiya Biltamlik/Wa Iqtina adalah perjanjian sewa menyewa suatu barang yang diakhiri dengan perpindahan kepemilikan barang dari pihak yang memberikan sewa kepada pihak penyewa. ${ }^{31}$

28 Fordebi dan Adesy, Akuntansi Syariah: Seri Konsep dan Aplikasi Ekonomi dan Bisnis Islam, Jakarta: Rajawali Pers, 2016, hlm. 288.

${ }^{29}$ Veithzal Rivai dan Arviyan Arifin, hlm.687.

30 Veithzal Rivai dan Arviyan Arifin, hlm. 687.

31 Veithzal Rivai dan Arviyan Arifin, hlm. 688. 
Pembiayaan merupakan salah satu produk pada BRI Syariah, Produk Pembiayaan pada setiap perbankan Syariah merupakan salah satu kegiatan yang dijadikan sumber pendapatan. Karena perkembangan pembiayaan pada usaha perbankan syariah maka pihak pengelola atau pengurus perbankan sebaiknya selalu memperhatikan tingkat pembiayaan sebagai suatu poduk yang mempunyai nilai jual yang tinggi kepada pihak nasabah.

\section{Temuan}

Dari uji analisis diatas maka penulis dapat merumuskan analisis hasil penelitian tersebut sebagai berikut:

1. Setelah melakukan pengujian asumsi klasik maka data yang ada layak dan memenuhi syarat untuk diteliti lebih lanjut. Dengan alat uji ini yang terjadi adalah berdistribusi normalitas, tidak ada multikoliniearitas, tidak ada heteroskedastisitas dan tidak ada autokorelasi.

2. Adapun dari hasil analisis regresi berganda Pengaruh Inflasi dan Margin Keuntungan terhadap Pembiayaan pada PT. BRI Syariah Jambi ini menghasilkan bahwa setiap kenaikan satu persen tingkat Inflasi maka pembiayaan yang disalurkan akan turun sebesar (-) 42,8\%. Jadi Inflasi mempunyai pengaruh negatif terhadap pembiayaan yang disalurkan. Sedangkan setiap ada peningkatan satu persen margin keuntungan maka pembiayaan yang disalurkan akan meningkat sebesar 2,21\%. Sehingga margin keuntungan mempunyai pengaruh positif terhadap pembiayaan yang disalurkan.

3. uji t atau uji secara parsial untuk variabel Inflasi $\left(\mathrm{X}_{1}\right)$ diperoleh thitung sebesar -6.312717 dengan signifikansi 0.0000 . nilai signifikansi lebih kecil dari $0.05(0.0000<0.05)$. maka diperoleh $t_{\text {tabel }}$ dengan $\mathrm{df}=48$ adalah sebesar 1.677. maka diperoleh thitung (-)6.312717 $>t_{\text {tabel }}$ (1.677) sehingga $\mathrm{H}_{0}$ ditolak dan $\mathrm{H}_{\mathrm{a}}$ diterima. Maka Inflasi berpengaruh signifikan terhadap pembiayaan yang disalurkan oleh PT.BRI Syariah di Jambi. Nilai koefisien regresi berganda mempunyai tanda negatif, artinya jika tingkat Inflasi meningkat maka pembiayaan yang akan disalurkan mengalami penurunan. Sedangkan uji t atau secara parsial untuk variabel Margin Keuntungan $\left(\mathrm{X}_{2}\right)$ diperoleh $t_{\text {hitung }}$ sebesar 1.885936 maka diperoleh $t_{\text {tabel }}$ dengan $\mathrm{df}=48$ adalah sebesar 1.677. maka diperoleh $t_{\text {hitung }}(1.885936)>$ $t_{\text {tabel }}$ (1.677) sehingga $\mathrm{H}_{0}$ ditolak dan $\mathrm{H}_{\mathrm{a}}$ diterima. Maka margin keuntungan berpengaruh signifikan terhadap pembiayaan yang disalurkan pada PT.BRI Syariah Jambi. Nilai koefisien regresi dari hasil perhitungan regresi berganda mempunyai tanda positif, artinya jika margin keuntungan meningkat maka pembiayaan yang disalurkan akan mengalami peningkatan. Hal ini dapat disimpulkan bahwa margin keuntungan merupakan komponen yang mempengaruhi terhadap pembiayaan yang disalurkan pada PT.BRI Syariah periode 2014-2018.

4. Uji $F$ atau uji secara simultan (bersama-sama) nilai signifikansinya adalah dengan melihat nilai probabilitas $F_{\text {statistik }}$ yaitu sebesar 0.000000 
dan nilai $F_{\text {tabel }}$ sebesar 35.73760. Dasar pengambilan keputusan adalah tingkat signifikansinya sebesar $5 \%$ atau 0.05 . Dasar pengambilan keputusan yang lainnya adalah $\mathrm{F}_{\text {hitung }}$ harus lebih besar dari $\mathrm{F}_{\text {tabel }}$ untuk menentukan adanya pengaruh dari variabel independen terhadap dependen. Dari perhitungan diatas diperoleh nilai $F_{\text {hitung }}$ yang besarnya 35.73760 yang lebih besar dari $F_{\text {tabel }}$ sebesar 1.47 (35.73760> 1.47) dan nilai $\mathrm{F}_{\text {statistik }}$ yaitu sebesar 0.000000 lebih kecil dari niai signifikansinya $(0.000000<0.05)$ maka dapat disimpulkan bahwa variabel Inflasi dan Margin Keuntungan secara simultan (bersama-sama) berpengaruh terhadap pembiayaan yang disalurkan oleh Bank BRI Syariah periode 2014-2018.

5. Uji Determinasi $\mathrm{R}^{2}$ yaitu nilai koefisien determinasi memiliki Adjusted Rsquare sebesar 0.586411. hal ini berarti pembiayaan (Y) yang disalurkan dapat dijelaskan oleh variabel $\mathrm{X}_{1}$ (Inflasi) dan $\mathrm{X}_{2}$ (Margin Keuntungan) sebesar 0.586411 (58,64\%). Sedangkan sisanya 41,36\% dijelaskan oleh faktor lain yang tidak diteliti dalam pengujian ini. Nilai koefisien korelasi (R) sebesar 0.603293 menunjukkan bahwa kuat hubungan antara variabel independen terhadap dependen sebesar 60,33\%. Dari hasil analisa ini dapat disimpulkan bahwa tingkat inflasi dan margin keuntungan berpengaruh terhadap jumlah pembiayaan pada BRI Syariah Jambi.

6. Analisis akhir menggambarkan bahwa tingkat Inflasi naik, maka tingkat pembiayaan pada PT. BRI Syariah turun dan apabila Margin Keuntungan naik maka Pembiayaan pada BRI Syariah meningkat. Hal ini sejalan dengan Teori Dornbus dan Fischer yang mengatakan Tingginya Inflasi maka nilai mata uang menurun dan menyebabkan masyarakat dirugikan atau setidaknya tidak diuntungkan, dengan demikian dana yang dihimpun bank menjadi lebih kecil.

7. Dari hasil uji tersebut menggambarkan bahwa jika tingkat Inflasi naik maka akan menurunkan nilai Pembiayaan dan jika nilai Margin Keuntungan naik maka akan meningkatkan nilai Pembiayaan. Dan hal ini berbanding terbalik dengan logika Penulis dilapangan yang mengasumsikan bahwa jika inflasi naik maka nasabah akan cenderung mengalihkan pinjamannya sebagai modal usaha ke perbankan Syariah yang prosesnya menggunakan sistem akad Pembiayaan Syariah.

\section{Penutup}

Sebagaimana telah diuraikan melalui temuan penelitian, dapat disimpulkan bahwa tingkat inflasi dan margin keuntungan berpengauh signifikan terhadap meningkatnya akad pembiayaan pada PT. BRI Syariah Jambi. Berdasarkan data dan hasil analisis yang telah dilakukan maka dapat diambil kesimpulan pula bahwa hasil uji t atau uji parsial Inflasi berpengaruh dan signifikan terhadap pembiayaan yang disalurkan oleh PT.BRI Syariah di Jambi, dan Inflasi Margin Keuntungan secara simultan (bersama-sama) 
berpengaruh terhadap pembiayaan yang disalurkan oleh Bank BRI Syariah. Kesimpulan ini dapat menjadi bahan pertimbangan bagi pihak-pihak yang terkait.

\section{Bibliografi}

Bambang Riyanto, Dasar-dasar pembelanjaan perusahaan, Yogyakarta:Gajah Mada, 2001.

Boediono, Pengantar Ilmu Ekonomi Makro, Yogyakarta: BPFE, 2016.

Bunga, Pinjaman Perbankan di Indonesia Periode Juli 2005 - Desember 2011, Jurnal Ilmiah, Universitas Brawijaya, Malang, 2013.

Detri Karya, Makro ekonomi: Pengantar untuk Manajemen, Jakarta: Rajawali Pers, 2016

Fordebi dan Adesy, Akuntansi Syariah: Seri Konsep dan Aplikasi Ekonomi dan Bisnis Islam, Jakarta: Rajawali Pers,2016.

Huda Nurul, dkk, Ekonomi Makro Islam Pendekatan Teoritis, Jakarta: Kencana Prenada Media Group, 2009.

Irfan Syauqi Beik, dkk. Ekonomi Pembangunan Syariah. Jakarta Rajawali Pers, 2016.

Kasmir. Bank dan Lembaga Keuangan Lainnya. Jakarta: PT. Raja Grafindo Persada: 2014.

Muhammad Umer Chapra, Monetary Management in An Islamic Economy, Islamic Economic Studies, Vol. 4, No. 1, Desember 1996.

S Munawir, Analisis laporan Keuangan, Yogyakarta: Liberty, 2007.

Nopirin, Ekonomi Moneter, Yogyakarta, BPFE,2013.

Rozalinda, Ekonomi Islam: Teori dan Aplikasinya pada Aktivitas Ekonomi, Jakarta: Rajawali Pers, 2014.

Saekhu, Pengaruh Inflasi Terhadap Kinerja Pembiayaan Bank Syariah, Volume Pasar, Uang Antar Bank Syariah dan Posisi Outstanding Sertifikat Wadiah Bank Indonesia", Jurnal ECONOMICA Pemikiran dan Penelitian Ekonomi Islam Vol. VI, 2015.

Soemitro Warkum, Asas perbankan Islam \& Lembaga-lembaga terkait amui, Takaful, dan pasar modal di Indonesia, Jakarta: Raja Grafindo Persada, 2004.

Sofyan Syafri Harahap,Teori Akuntansi, Jakarta:Raja Grafindo

Suad Husnan dan Enny Pudjiastuti, Manajemen Keuangan, Yogyakarta: BFEE, 2004.

Thamrin Abdullah dan Francis Tantri. Bank dan Lembaga Keuangan. Jakarta: Rajawali Press.

Umer Chapra dan Habib Ahmed. Corporate Governance Lembaga Keuangan Syariah. Jakarta: Bumi Aksara, 2008. 